GEOLOGICAL SURVEY CIRCULAR 611

\title{
Asbestos Occurrence in the Eagle C-4 Quadrangle Alaska
}

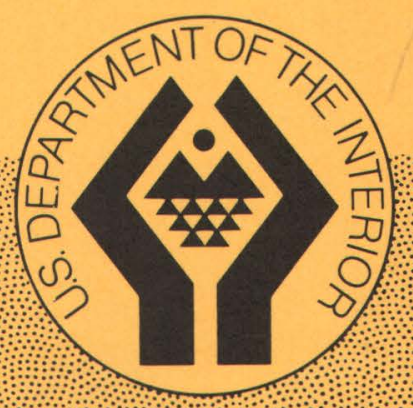





\section{Asbestos Occurrence in the Eagle C-4 Quadrangle Alaska}

By Helen L. Foster

GEOLOGICAL SURVEY CIRCULAR 611

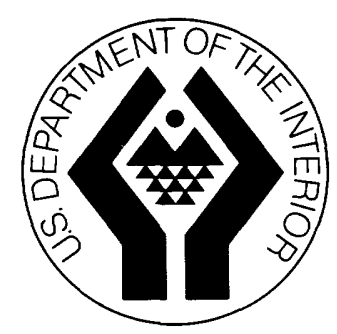


United States Department of the Interior STEWART L. UDALL, Secretary

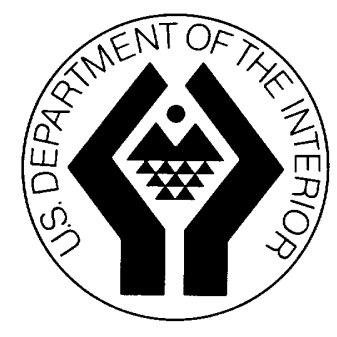

Geological Survey

William T. Pecora, Director 
Abstract - . -

Introduction -...

Physiographic setting and access -

Regional geologic setting

Geology of the asbestos occurrence and vicinity

Description of occurrence

Summary of asbestos occurrences in the Eagle quadrangle and

suggestions for prospecting -

References cited-_.

\section{ILLUSTRATIONS}

Figure 1. Index maps showing location of Eagle quadrangle and asbestos occurrence described in this report-......-.

2. Geologic map of vicinity of asbestos occurrence described in this report

3. Map showing asbestos and ultramafic rock occurrences in the Eagle quadrangle

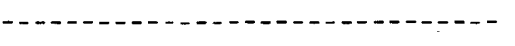




\section{Asbestos Occurrence in the Eagle C-4 Quadrangle, Alaska}

By Helen L. Foster

ABSTRACT

An asbestos occurrence was discovered in a remote part of the Eagle quadrangle, Alaska, in the summer of 1968 during geologic reconnaissance in connection with the U.S. Geological Survey's Heavy Metals program. The exposed part of the deposit consists of large joint blocks of serpentine which are cut by closely spaced subparallel veins. Most of the veins are about $\frac{1}{4}$ inch thick, and they consist of cross-fiber chrysotile asbestos. The asbestos appears to be of commercial quality, but the total quantity is unknown.

The asbestos occurs in a serpentinized ultramafic mass which appears to intrude metamorphic rocks. Many other serpentinized ultramafic masses are known in the Eagle quadrangle, but this is the first one in which considerable asbestos has been found. The deposit is of importance because it shows that geologic conditions are locally favorable for the formation of asbestos in the YukonTanana Upland, and hope of finding commercial asbestos deposits thus seems possible.

\section{INTRODUCT ION}

An asbestos occurrence was discovered in the Eagle quadrangle, Alaska (fig. 1), in August 1968 during geochemical sampling and geologic reconnaissance in connection with the U.S. Geological Survey's Heavy Metals program. This is the first occurrence of asbəstos reported in the Eagle quadrangle, although asbestos is being mined 55 miles to the east-southeast on Clinton Creek in the Yukon Territory, Canada. The asbestos is in a serpentinized ultramafic mass located in mountainous terrain about $36 \frac{1}{2}$ miles west of the Taylor Highway; it is on the eastern border of the Eagle C-4 quadrangle, 42 miles southwest of the village of Eagle. Even though this occurrence is probably not large enough to be of commercial interest at present, it indicates that geologic conditions necessary for the formation of asbestos did occur in this part of Alaska, and thus gives hope for finding other serpentinized ultramafic masses with commerical quantities of asbestos in the Yukon-Tanana Upland.

Little detailed geologic information is available on the central part of the Eagle quadrangle. The most recent published geologic map of the area (Mertie, 1937) is not sufficiently detailed to show small occurrences of ultramafic rock. The present report is based on 1 day's fieldwork on foot in the general area covered by the geologic map (fig. 2) and is also based on additional fieldwork in the eastern part of the quadrangle.
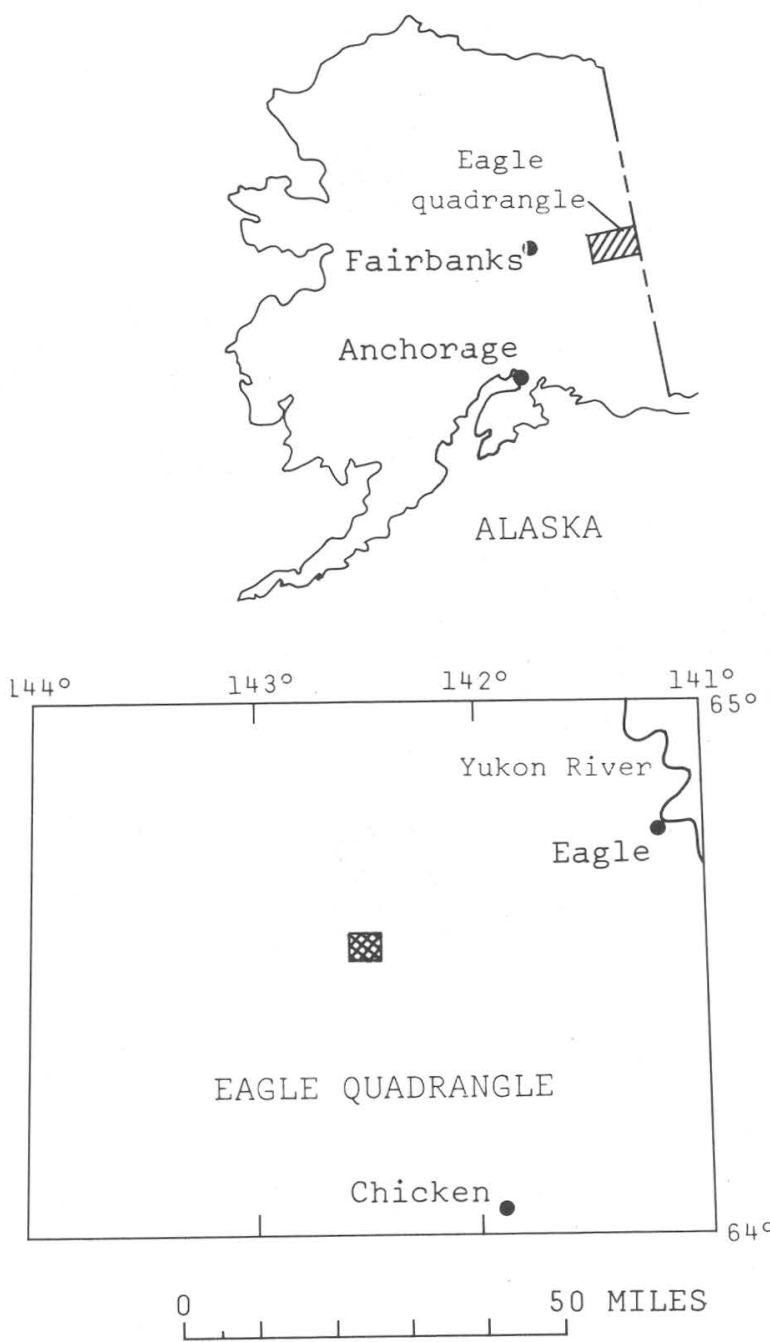

Figure 1.- Index maps showing location of Eagle quadrangle and asbestos occurrence described in this report. Area shown in figure 2 is crosshatched. 


\section{EXPLANATION}

UNCONSOLIDATED DEPOSITS

$$
\because C \mathrm{Cza} \because 0^{\circ}
$$

Colluvium and alluvium

\section{PLUTONIC ROCKS}

$$
\stackrel{+}{+\mathrm{MZZh}_{+}^{+}+}
$$

Hornblende adamellite

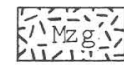

Granodiorite

METAMORPHIC ROCKS

\section{$\mathrm{MzPzS}$}

Serpentinite with crossfiber asbestos

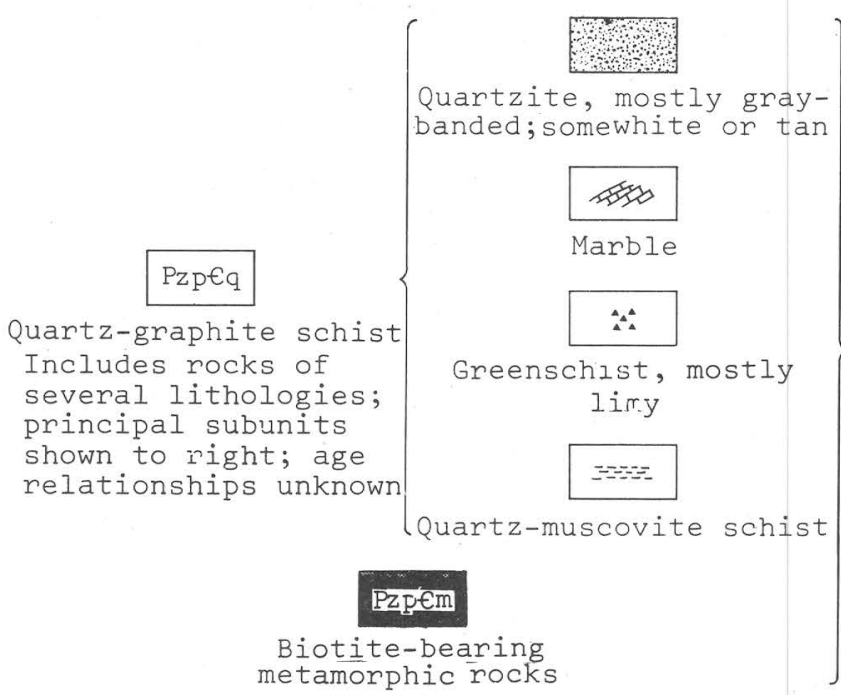

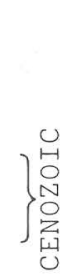

0
$H$
0
$N$
0
0
岁

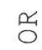

3

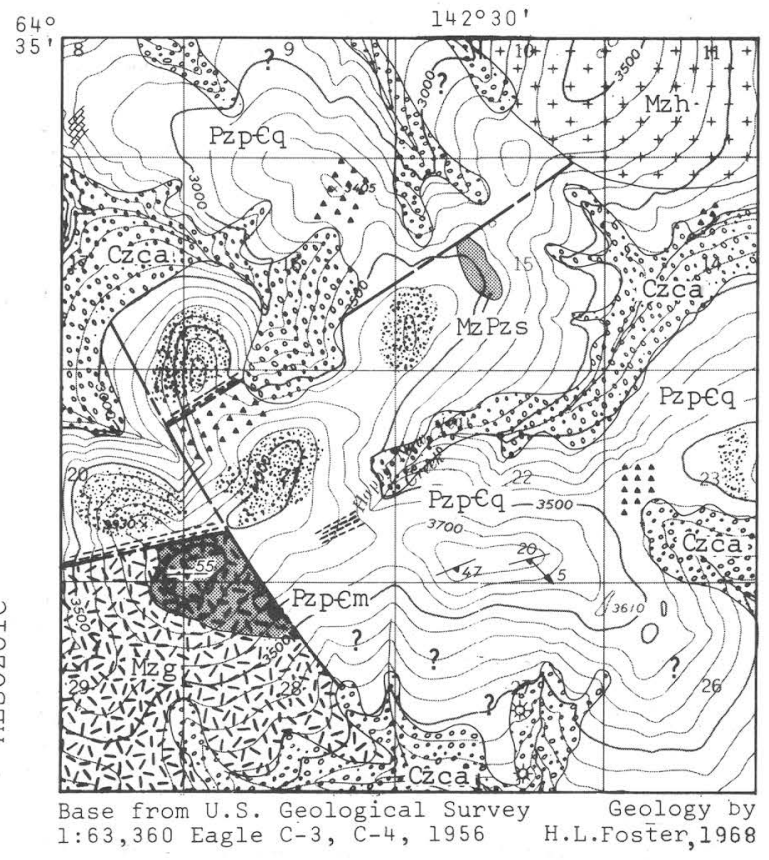

$0 \quad 1 / 2 \quad 1$

2 MILES

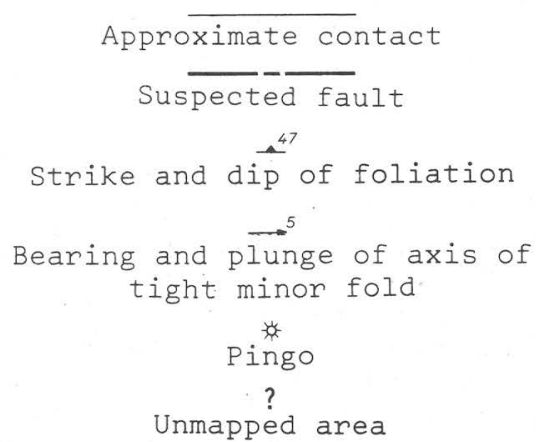

Figure 2.-Geologic map of vicinity of asbestos occurrence described in this report. 
Physiographic Setting and Access

The asbestos occurrence is in the central and eastern parts of the Yukon-Tanana Upland as defined by Wahrhaftig (1965, p. 24). The area is unglaciated and consists of wooded and brush-covered ridges and valleys. The ridges range in elevation from 3,000 to nearly 5,000 feet and relief is about 600 to 1,600 feet. The deposit is on a northeast-trending $\mathrm{ridge}$, at an elevation of about 3,500 feet, between Happy New Year and Bryan Creeks (fig. 3), which are tributaries to Slate Creek. This ridge extends northeast from the main ridge which forms the divide betweendrainage into the middle fork of the Fortymile River to the south and Slate Creek to the north.

Access to the area is difficult because the nearest road, the Taylor Highway, is $36 \frac{1}{2}$ miles to the e a st. The nearest usable landing strip is 23 miles to the southwest, on the middle fork of the Fortymile River at the site of the former settlement of Joseph (fig. 3). Although the landing strip is partly overgrown with brush, small bush planes (Cessna 180 or smaller) can land there. There is also a short abandoned landing strip partly overgrown with brush on the ridge between Gold Run and Jim Creek 8 miles west of the deposit. The outcrop containing asbestos is sufficiently clear of trees and brush that, with caution, a small helicopter can land there or on quartzite half a mile to the southwest.

\section{REGIONAL GEOLOGIC SETTING}

The eastern part of the Yukon-Tanana Upland is a complex metamorphic terrane that has been intruded at intervals over a long span of time by felsic, mafic, and ultramafic rocks. In places Tertiary sedimentary and volcanic rocks lie unconformably on, or are in fault contact with, metamorphic rocks or older igneous rocks. The northern boundary of the metamorphic terrane is a major zone of faulting called the Tintina trench (Roddick, 1967, p. 23). The metamorphic rocks range in grade from greenschist to amphibolite facies and are of both sedimentary and igneous origin. Most of the metamorphic rocks are of unknown age, but some are of Paleozoic age as shown by poorly preserved crinoid columnals in marble.

Ultramafic rocks crop out in many places throughout the Eagle quadrangle. Mapping of the Tintina fault zone, although incomplete, suggests one or two northwest-trending linear zones, parallel to the trend of the Tintina trench, along which ultramafic masses are exposed. Other ultramafic outcrops appear to have a random distribution. Many of the ultramafic bodies are associated with greenstones and $\mathrm{greenschists.}$ Most of the ultramafic rocks have been wholly or partly serpentinized; the serpentine has been identified as antigorite in specimens that have been checked by X-ray diffraction. The age of the ultramafic rocks is unknown, but they are tentatively considered to be late Paleozoic or early Mesozoic because they appear to intrude the metamorphic rocks and because they are probably older than the plutonic rocks of middle or late Mesozoic age. The ultramafic rocks may be somewhat more abundant than shown in figure 3 because mapping has not been sufficiently detailed to find some small outcrops. Ultramafic rock in stream float definitely indicates the presence of other occurrences.

\section{GEOLOGY OF THE ASBESTOS OCCURRENCE AND VICINITY}

The serpentinized rock containing asbesto ${ }^{\circ}$ crops out as an elongate mass apparently cutting greenschist facies metamorphic rocks (fig. 2 ). It is the onl't known outcrop of either serpentinite or ultramafic ro:k in the vicinity. The nearest ultramafic rock, also serpentinized and also having some thin bands of asbestos, occurs 24 miles to the east-southeast (fig. 3).

Granitic rocks also cut the metamorphic rccks and crop out about $2 \frac{1}{4}$ miles southwest, a little over half a mile northeast, and 2 miles west of the asbestos occurrence. The granitic rock to the northeast is a medium-grained hornblende adamellite. It is part of a small pluton that is probably about 1 square mile in area. The rock is fairly dark colored because of the abundance of hornblende. The potassium feldspar is microcline and the plagioclase is oligoclase. Sphene and apatite are abundant accessories. The granitic rock to the southwest, which is part of a pluton several square miles in area, is mostly granodiorite. The rock is fine to fairly coarse grained, and most of it is medium grained. Biotite is the principal mafic mineral, but some of the exposures are relatively low in biotite and consist dominantly of quartz and feld spar. The granitic rock to the west (outside the area shown in fig. 2) is possibly a dike and is coarse grained with pink feldspar; in places it is green owing to epidote. Its extent is not known.

The metamorphic country rock is mostly gray, white, and tan quartzite, quartz schist, and quartz-muscovite schist; gray quartz-graphite schist; and green chlorite schist and limy chlorite schist. Quartz-biotite schist and impure quartzite with fine-grained biotite occur in one area (fig. 2). The most abundant rock is gray quartzite, much of which is banded. It is a type characteristic of greenschist facies metamorphic rocks that are abundant to the east and have been mapped as a quartz-graphite schist unit (Foster and Keith, 1968). Gray quartz-graphite schist is the dominant rock type on the east-trending ridge south of the ultramafic mass. Thin bands of white quartz-muscovite schist, interlayered in quartzite, are evident in several places (fig. 2). Greenschist, most of which is limy, crops out in four places (fig. 2) and may represent two northor northeast-trending bands.

The metamorphic rocks are complexly deformed and cut by numerous faults, but because good outcrops are rare, details of structure are not evident. Rock types are determined largely on the basis of rubble, and only a few reliable strike and dip measurements w e r e obtained. 


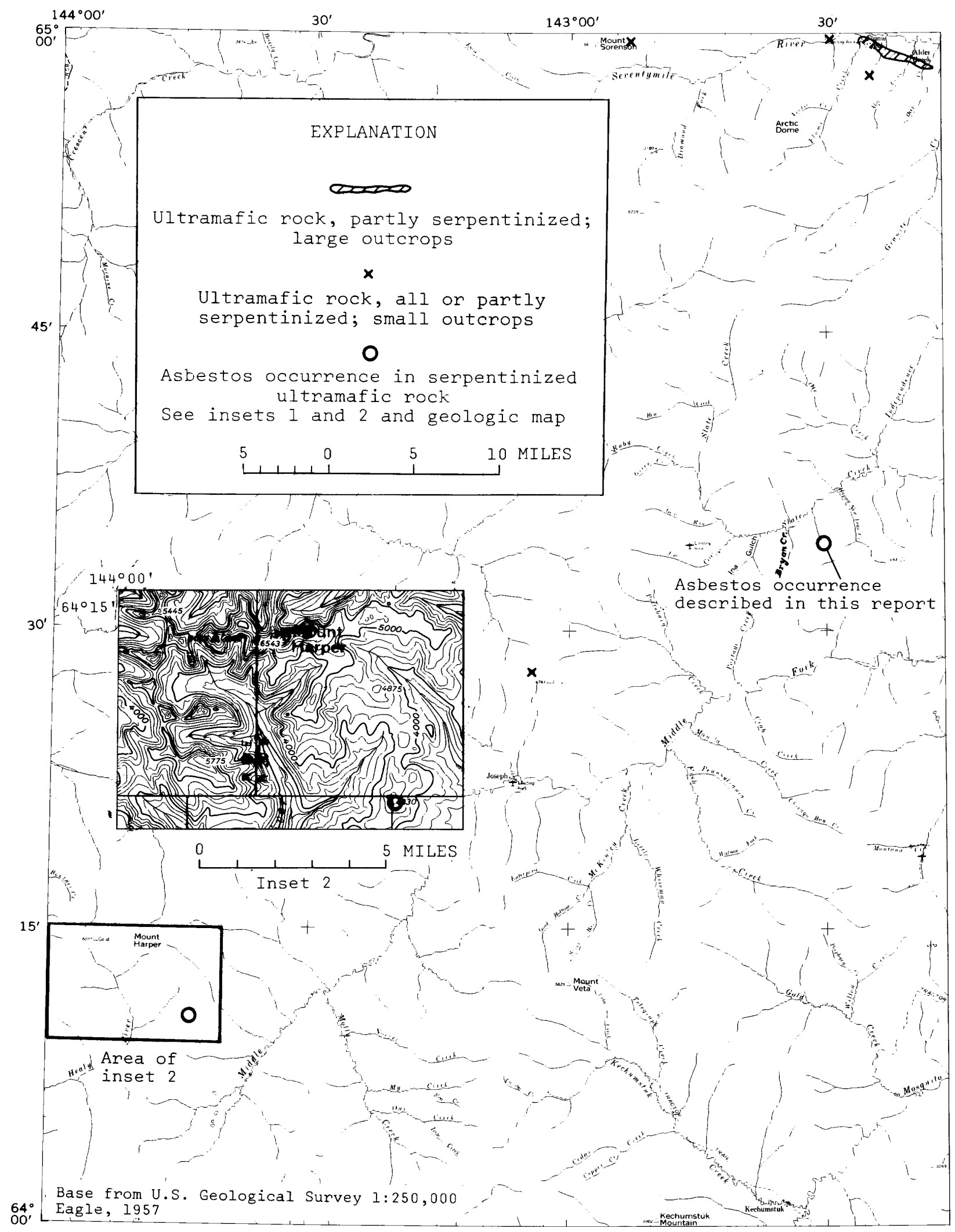

Figure 3.-Asbestos and ultramafic rock occurrences in the Eagle quadrangle. 


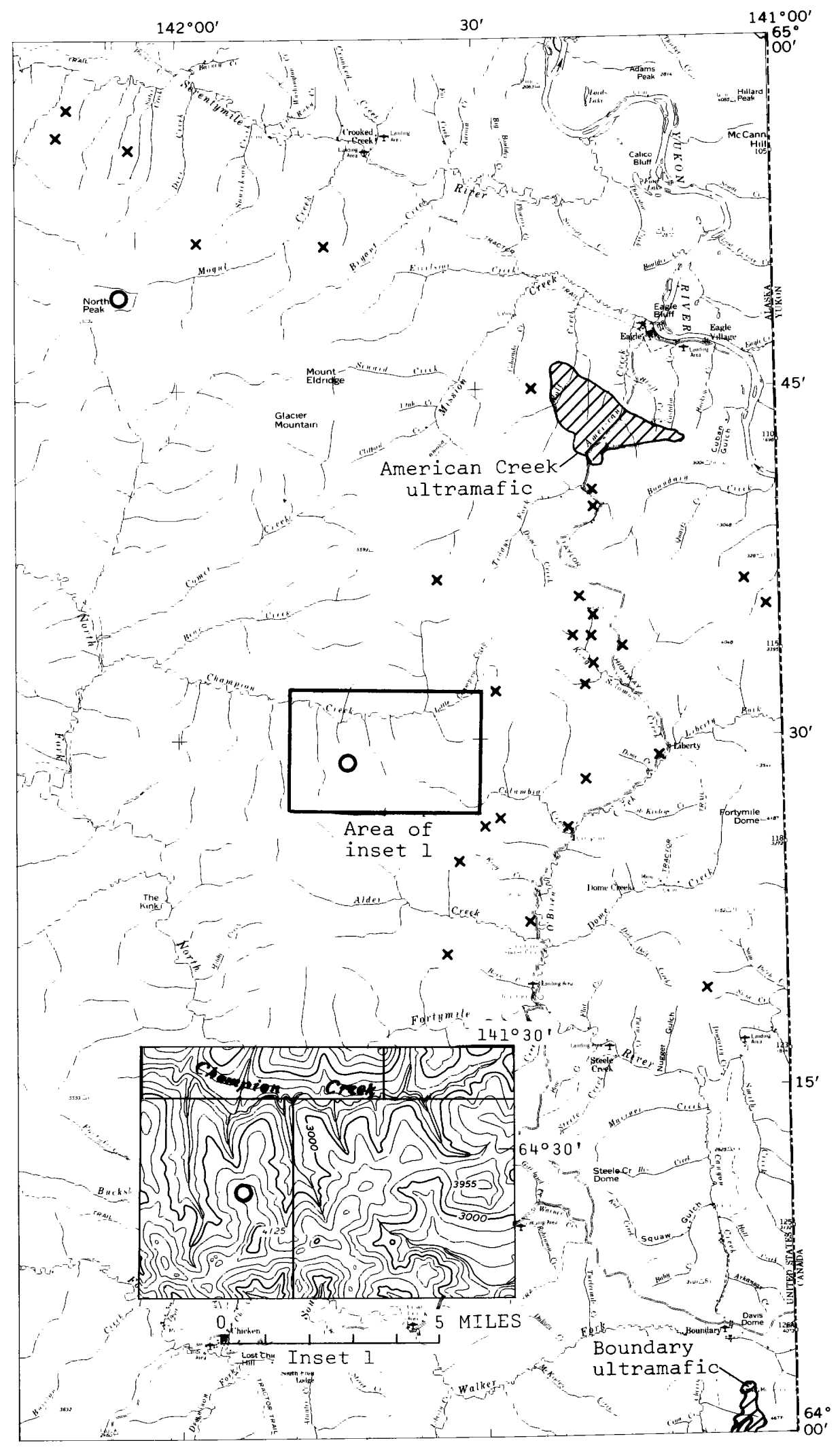

Figure 3.-Continued. 


\section{Description of Occurrence}

The asbestos occurrence consists of large joint blocks of dark-gray, black, and dark-greenish and brownish-black serpentine (antigorite). The approximate extent of the mass, as determined from limited ground observations and a study of aerial photographs, is shown on the map (fig. 2). The well-exposed part of the outcrop, all of which is believed to contain asbestos, is about 500 feet long and 200 feet wide and rises 30 feet or more above the main level of the ridge. The rock is cut by closely spaced (mostly from one to a few inches apart) subparallel veins of cross-fiber chrysotile asbestos that range in width from $1 / 8$ inch to about $3 / 4$ inch. Most of the veins are about $1 / 4$ inch wide and many are compound. In the limited exposure examined, the asbestos veins cutting the massive serpentine would, if the occurrence were large enough, be sufficiently abundant and of good enough quality to have commercial value.

\section{SUMMARY OF ASBESTOS OCCURRENCES IN THE EAGLE QUADRANGLE AND SUGGESTIONS FOR PROSPECTING}

Because asbestos generally occurs in veins in ser pentinized ultramafic rocks, knowledge of the occur rence of ultramafic rocks in an area is useful in the search for commercial asbestos deposits. Occurrences of ultramafic rocks that are known in the Eagle quadrangle are shown in figure 3 (for more exact location of many localities see Foster and Keith, 1968). Chrysotile asbestos has been found in the deposit described in this report, south of Champion Creek in the Eagle B-2 quadrangle (fig. 3), 51/2 miles southeast of Mount Harper in the Eagle A-6 quadrangle (fig. 3 ), and 1 1/2 miles east of North Peak in the Eagle D-3 quadrangle (fig. 3). At the locality south of Champion Creek only pieces of float with a few narrow $(1 / 8 \mathrm{inch})$ veinlets of asbestos have been found in the vicinity of serpentinized ultramafic rock. The ultramafic rock is bounded on the south by greenschist. Southeast of Mount Harper, asbestos has been found in float around an outcrop of partially serpentinized peridotite. The peridotite occurs in large block s 4 feet or more in diameter. From a distance the outcrop can be recognized by its pinkish-brown color. The fiber is about 2 inches long and is probably slip fiber but none has been found in place. Serpentinized ultramafic rock east of North Peak contains a few tiny veinlets, almost microscopic in size, of asbestos. Some of the other ultra m a f i c masses, including the one along American Creek and the one south of Boundary (fig. 3 ), locally have fibrous serpentine but the fibers are stiff.

The conditions that have caused the formation of asbestos in some of the serpentinized ultramafic bodies but not in others are not known, although some geologists have suggested that faulting is an important factor. Most of the Yukon-Tanana Upland is complexly faulted, but extensive cover makes it difficult to locate and trace faults. Marker beds are not generally present, and in many places small local faults are difficult to distinguish from large regional faults.
Some of the ultramafic bodies, particularly in the eastern part of the quadrangle, are associated with greenstone of probable andesitic and basaltic composition. Many serpentinized bodies, however, including the one described in this report, are not associated with greenst ones. Some serpentinization of greenstones of probable basaltic or andesitic origin has been noted, but no fibrous material has been discovered. The serpentinization of greenstones is less common and less extensive than that of the ultramafic rocks.

Most of the ultramafic rocks are in areas of greenschist facies metamorphic rocks. Only a few bodies of ultramafic rock have been found in the areas of amphibolite facies metamorphic rocks, and some of them are not serpentinized. This observation, however, should not preclude further exploration in areas of higher grade metamorphic terrane, as its significance, if any, is unknown.

Prospectors searching for asbestos deposits in the Eagle quadrangle may find the following criteria useful for recognizing ultramafic rocks, including those that have been serpentinized. The fresh ultramafic rock commonly is dark gray, black, or greenish black; weathered surfaces may be grayish brc'vn, pink is h brown, or greenish gray. The rock is generally massive and is heavier than the other local rocks. Ultramafic rocks may occur as large or small irregular masses and as dikes and sills. Concertrations of boulders of ultramafic rocks in streams are generally not far from their outcrop, and the outcr op can usually be located by following the stream float. Outcrops of ultramafic rocks are characteristically almost bare or vegetation is sparse. However, some of the quartzite outcrops in the area also have sparse vegetation.

No pattern useful for prospecting has been observed in known outcrops of ultramafic rocks of the Eagle quadrangle (fig. 3 ). One or two belts of serpentinized ultramafic rock occur along faults parallel to the Tintina trench, but no asbestos has yet been found. Significant structure related to the occurrence of other ultramafic outcrops is unknown.

Parts of the Yukon-Tanana Upland nt recently mapped probably contain several undiscovered ultramafic bodies. These areas include the western part of the Eagle quadrangle and much of the Big Delta quadrangle, especially the eastern part. The Tanacross (Foster, 1968), Charley River (Brabb and Churkin, 1964), and eastern part of the Eagle (Foster and Keith, 1968) quadrangles have recent ly been mapped, but because much of the mapping is only reconnaissance there are some undiscover ed ultramafic bodies in the these areas.

The Eagle quadrangle is covered by an aeromagnetic survey (Brosgé and others, 1968), but the lines of flight are too widely spaced (10 miles) to givo much aid in locating small bodies of ultramafic rock. More detailed aeromagnetic surveys would be very useful in searching for asbestos. 


\section{REFERENCES CITED}

Brabb, E. E., and Churkin, Michael, Jr., 1964, Preliminary geologic map of the Charley River quadrangle, east-central Alaska: U.S. Geol. Survey open-file report.

Brosgé, W. P., Brabb, E. E., and King, E. R., 1968, Geologic interpretation of reconnaissance aeromagnetic survey of northeastern Alaska:U.S. Geol. Survey open-file report.

Foster, H. L., 1968, Reconnaissance geologic map of the Tanacross quadrangle, Alaska: U.S. Geol. Survey open-file report.
Foster, H. L., and Keith, T. C., 1968, Preliminary geologic map of the Eagle $\mathrm{B}-1$ and $\mathrm{C}-1$ quadrangles, Alaska: U.S. Geol. Survey open-file report.

Mertie, J. B., Jr., 1937, The Yukon-Tanana r egi on, Alaska: U.S. Geol. Survey Bull. 872, 276 p.

Roddick, J. A., 1967, Tintina trench: Jour. G e ology, v. 75 , no. 1 , p. 23-32.

Wahrhaftig, Clyde, 1965, Physiographic divisions of Alaska: U.S. Geol. Survey Prof. Paper 482, 52 p. 
